Journal of Critical Race Inquiry

Volume 3, Number 1 (2016) pp. 61-86

\title{
Beyond Sir John: Unsettling Public Memory in Kingston, Ontario
}

\author{
Laura J. Murray \\ Department of English and Graduate Program in Cultural Studies, Queen's \\ University
}

Paul Carl (Obiziindan Animitagozi Noodin)

\begin{abstract}
This essay begins with a discussion of how provincial and municipal policy and practice in Kingston has defined "heritage" in such a way as to reinforce class and race privilege. It then offers a critical documentation of the Macdonald bicentennial in Kingston, which has not been done synthetically elsewhere. Finally, it describes some alternative plaques the authors proposed at an Indigenous Symposium on the eve of the bicentennial as a way of insisting on Indigenous presence in the city and challenging triumphalist state narratives. ${ }^{1}$
\end{abstract}

Keywords: commemoration, Kingston, Ontario, heritage, place, indigenization

\footnotetext{
${ }^{1}$ Miigwetch to David Garneau, Jim Daschuk, and Jen Hardwick for inspiration, information, and assistance with this work. And thanks to Leah Decter, Erin Sutherland, Jan Hill, Dorit Naaman, and various Kingston community members for doing so much to assert a critical perspective on Macdonald and create a supportive environment for anticolonial projects. We also commend Paul Robertson, Colin Wiginton, and Terri-Lynn Brennan for their ongoing work to bring Indigenous perspectives more prominence at the City of Kingston.
} 


\section{Introduction}

2015 was the 200th anniversary of the birth in Scotland of Sir John A. Macdonald, Canada's first Prime Minister (1815-1891), whose childhood home and seat of political power was Kingston, Ontario. To mark the occasion, the Kingston-based Sir John A. Macdonald Bicentennial Commission set out "to inspire a greater appreciation of the life and contributions of...Canada's Father of Confederation, by promoting events in the arts, education, tourism and other sectors...and to create an ongoing celebration befitting Canada's greatest statesman” (Funding Request to Kingston City Council: Introduction, 2013, p. 78). To Kingston residents aware of Macdonald's role in the starvation of Indigenous people during his lifetime and in their oppression since as a consequence of policies he inaugurated, the celebratory bias of bicentennial observances was problematic if not distressing. The authors of this essay first met as members of Kingston's Municipal Heritage Committee. ${ }^{2}$ We were not part of the bicentennial planning or execution, but in the year preceding the bicentennial we felt implicated and uncomfortable with what was being billed as "the biggest birthday party in Canadian history" (Jansman, 2015, p. 56). Certainly, celebration of Macdonald is not new in Kingston: plaques, statues, and honorific namings abound in the city, and you can't go anywhere without seeing them. But we are not sure that a lot of white settler Kingstonians do see them, or think about their implications, and we were not keen on a renewed round of reverence and festivity. So we began to ponder what other claims and commemorations we might install on the streets of the city to surprise, inform, and challenge passers-by - white settlers, racialized people, and Indigenous people alike.

This essay begins with a discussion of how provincial and municipal policy and practice in Kingston has defined "heritage" in such a way as to reinforce class and race privilege. It then offers documentation of the Macdonald bicentennial in Kingston, which has not been done synthetically elsewhere. Finally, it describes some alternative plaques we proposed on the eve of the bicentennial at the $16^{\text {th }}$ Annual Symposium on Indigenous Research at Queen's University. In the context of Kingston's insistent and persistent inscription of white settler triumphalism, we imagined plaques speaking critique of the Canadian state and acknowledgment of Indigenous survival. We have not yet formally proposed or made any of these plaques - this was to start with a thought experiment - but we may well do so in future. We certainly hope that Kingston public spaces will include more acknowledgment of Indigenous history in some form and we expect to play a role in emerging

\footnotetext{
${ }^{2}$ As of 2016 Laura Murray has resigned, but she continues to serve on the Cultural Heritage Working Group of the City of Kingston.
} 
initiatives. It must also be noted that representation of the histories of Black and other racialized people is also imperative in the city, even if our focus here is on Indigenous histories, so this initiative is part of an even larger reinscription that needs to happen in the city.

We, the authors, have both lived in Kingston for about twenty years. Paul is a Katarokwi community member with Algonquin, Oneida, Dutch, and English roots, and grew up on the St. Lawrence River; he is a knowledge-sharer working to increase understanding of Indigenous traditions and issues, both within and beyond Indigenous communities. Laura is a white settler scholar of literature and Cultural Studies at Queen's University who grew up in Toronto; while her research has engaged Indigenous issues to various extents, this is not her main area of expertise. Neither of us is a scholar of critical race theory. Insofar as this essay constitutes "critical race inquiry," it does so not by applying theory to observed phenomena, but by intervening in and reflecting on the social and spatial context of our home in a way that we hope may suggest theoretical connections of interest to others. To us, the experience of the Macdonald bicentennial was very personal and experiential. Thus the essay moves between a more formal "academic" voice (what you are reading now), and selected transcriptions from conversations we have recorded, which can be found in the text boxes throughout the essay.

\section{The Exclusions of Kingston's Heritage Brand}

As a creature of the Ontario Heritage Act, the Municipal Heritage Committee is obliged to respond to requests to make changes to heritage buildings within a particular time frame, which leaves little room on meeting agendas to talk about how to preserve other dimensions or forms of history and memory (Procedural By-law for Heritage, 2013; Ontario Heritage Act, 1990). The City of Kingston's Culture Plan identifies the value of both "intangible" and "tangible" heritage - in principle allowing for a range of ways of knowing about connection to the past (City of Kingston, 2010, pp. 28-29). But both the Ontario Heritage Act and (in our observation) most members of the Municipal Heritage Committee take for granted that "heritage" simply means "heritage buildings." At least since Margaret Angus's The Old Stones of Kingston (1966), stone buildings have come to be a central marker of Kingston's identity and tourist "brand" as "The Limestone City." Of course, beautiful and significant old buildings continue to be at risk and it is appropriate that measures be taken to

\footnotetext{
${ }^{3}$ Although the Ontario Heritage Act does not refer to buildings in its title, it is focused on "Conservation of Property of Cultural Heritage Value or Interest" in which "property" is defined as "real property and includes all buildings and structures thereon." Its other main concern is "Resources of Archaeological Value," but nowhere does it deal with "heritage" that is not material in nature.
} 
protect them. But to us, heritage is rooted in memory, human experience, political economy, and place and displacement, and we are often more interested in dimensions of history not monumentalized in stone. As members of the Heritage Committee, we have felt that the parameters of "heritage" attention are far too narrow and indeed exclusionary. 4

With its diligent focus on the material, the rectangular, and the individual, the Heritage Committee works to preserve traces of those who bought land, built on it, and stayed on it or

I find myself thinking about the obsession with limestone in Kingston. I mean, there's a lot of it here, so it makes sense to notice it. I have no basement because the house is just built on rock. And we do have some beautiful stone buildings. I love that about Kingston. But another thing about limestone is, it's white. Well, apparently it isn't white when first hewn out of the ground, but it gets white after it's exposed to air for a while. Meanwhile, there are a lot of brick buildings here too-red ones! - and wood ones in lots of colours and aluminum and vinyl siding and whatever - and somewhere along the line it seems to have become normalized that they aren't as central to the city's image. I wonder whether this can be a metaphor for race. You know, yes, there are lots of non-white people around, but the feeling is, they aren't the essence of what Kingston is. They don't get noticed and protected and celebrated the same way.

- Laura Murray sold it. This approach effaces those who cut or lifted the stone, or who cut and lifted the firewood to heat the house and bake the breadbecause they were not owners or architects. It also continues this disproportionate focus on privilege into the present day by devoting the bulk of staff and committee "heritage" resources towards renovation projects of wealthy homeowners in the downtown area, thus amplifying the marginalization of renters and lower income residents. Misrepresentation of Kingston's past is not only shoddy history; it has social costs today. It is thus imperative, we think, for Kingston - its government,

its schools, its people - to imagine its history more broadly, to include those who have lived here since before it was "Kingston", as well as non-British immigrants and those who have inhabited this land not as owners or bosses or politicians, but as farmers, fishers, hunters, care-givers, laborers, or slaves. ${ }^{5}$

\footnotetext{
${ }^{4}$ As of April 2016, the City amalgamated the Heritage Committee and the Museums and Collections Advisory Committee, with the goal of integrating attention to "tangible" and "intangible" heritage. Members of the former Heritage Committee are resistant to this change. It remains to be seen whether it will succeed. ${ }^{5}$ Some of the Loyalists who came to Kingston following the American Revolution in the 1780s owned slaves. See "Black History." Stones. Available from: http://www.stoneskingston.ca/black-history/ and for the broader story, see Robin Winks, (2014), The Blacks in Canada: A History (2 ${ }^{\text {nd }}$ ed.). Montreal and Kingston: McGill-Queen's University Press, pp. 24-60.
} 
The myopic concern for "designated" buildings has particular implications for Indigenous history, as it makes it especially hard to see or remember those who have lived on the land, making dwellings to serve the purpose of the season, passing through and returning again. It makes it hard to perceive the circular, the traditional, and the collective. Kingston's "edifice complex" contributes to making Indigenous habitation Sometimes I think built heritage is a farce, because without a story behind that building, it's just rock. But someone built it, someone lived in it. To save a building just because it looks pretty, what about the story?

- Paul Carl and experience invisible. ${ }^{6}$ It is difficult to fit Indigenous concerns, experiences, and worldviews into the parameters of "heritage" as defined by provincial and municipal governments and accepted by the almost exclusively white settler "heritage community" of the city. And yet beyond this insular world of "heritage," Indigenous people continue to live and make indigeneity in Kingston.

I never really started following my traditional teachings until I moved back to Kingston in 1997 and that's when I started connecting with the community, working in the community. My father passed away in 1998, but before he passed away, he really started telling me stories about who we are, and he said, be proud of who you are, and start to follow your teachings.

I remember the day I approached a community member in Kingston, and it was really interesting, the first word out of his mouth was, "I know of your family." So it was almost like a "yes, I am a real Native person," because I was always raised that if you didn't have a status card, you weren't Native. But when someone says, yes, I know of your family, then you are; the piece of plastic doesn't matter.

When I was a kid, we were only two pages in a book. It seemed like when you turned the page, we just disappeared. And then I wondered, was I really Native because I didn't live on a reserve, and I was just like everybody else?

- Paul Carl

\section{Macdonald in Kingston}

Besides the limestone and other old buildings, the "jewel in the crown" of Kingston's heritage identity is Sir John A. Macdonald. There are eleven plaques about him in Kingston public spaces, on which Macdonald is described as the "Father of Confederation"; a "visionary statesman, determined Conservative politician, much-loved leader"; and a

\footnotetext{
${ }^{6}$ We borrow the phrase "edifice complex" from Brian Osborne, Professor Emeritus, Queen's University Department of Geography. Personal correspondence. )
} 
"Statesman and patriot."7 These plaques mark the locations, for example, of his childhood home, his law office, and the homes of family members. Macdonald's home, Bellevue House, is a museum run by Parks Canada. In addition, his grave at Cataraqui cemetery is much besigned and be-plaqued. A grand statue of Macdonald in a cape stands on a pedestal at the corner of City Park. Sir John A. Macdonald Boulevard is one of the town's major thoroughfares; Sir John A. Macdonald School is its newest elementary school; a locomotive in the park by City Hall has been dubbed "The Spirit of Sir John A."; and the law school at Queen's University is housed in Macdonald Hall. Most people arrive in Kingston from the west or east on the Macdonald-Cartier Highway, otherwise known as the 401. In other words, Macdonald is amply marked on the physical and mental landscape of this city. He is impossible to miss.

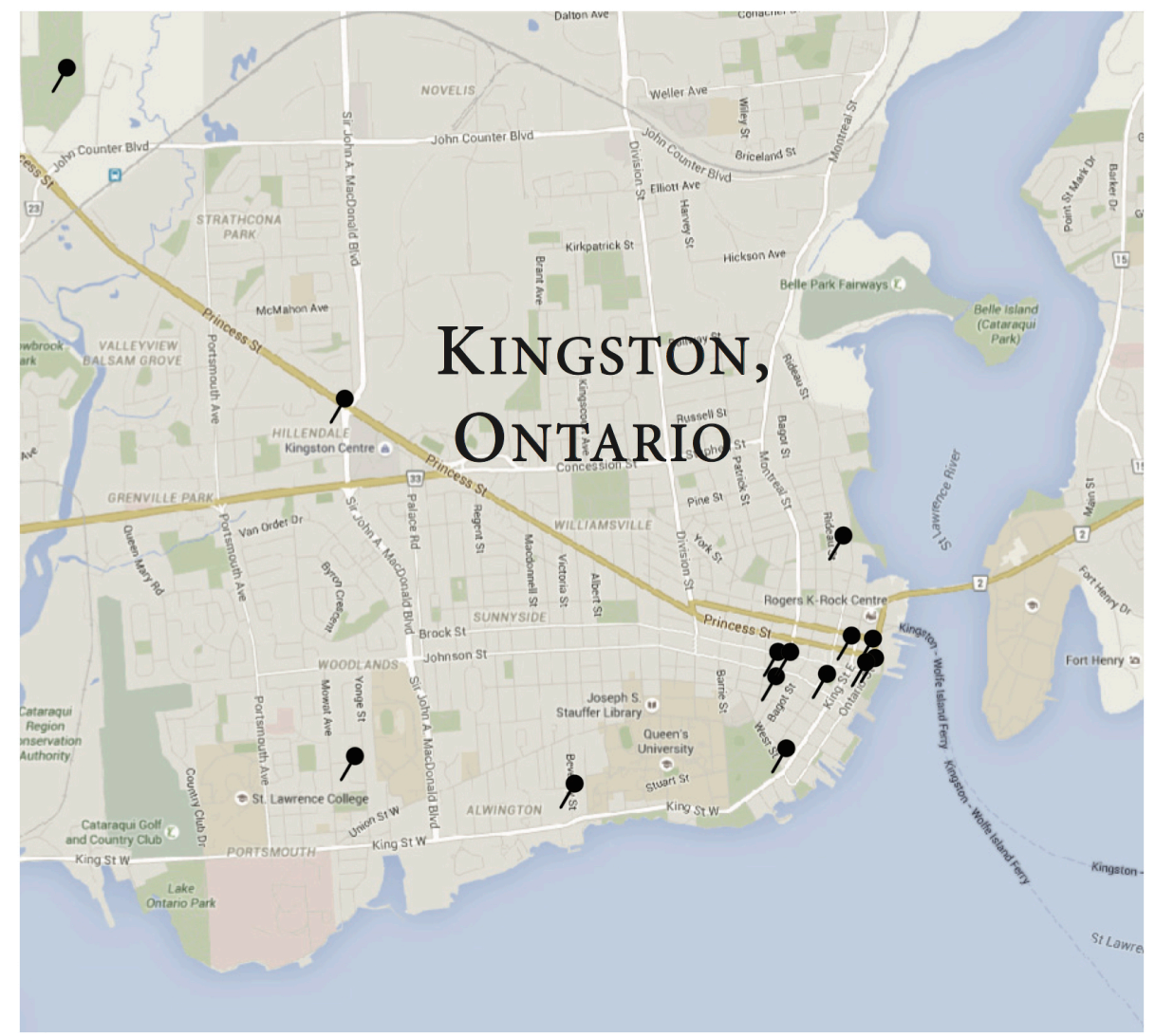

Figure 1: Location of historic plaques commemorating Macdonald in Kingston. (Photo Credit: Teresa Carlesimo with information from Kingston Historical Society).

\footnotetext{
7 Wording is from plaques located at 194 Johnson Street, 112 Rideau Street, and Macdonald's gravesite in the Cataraqui Cemetery, all in the City of Kingston and pictured in Figure 2 below.
} 


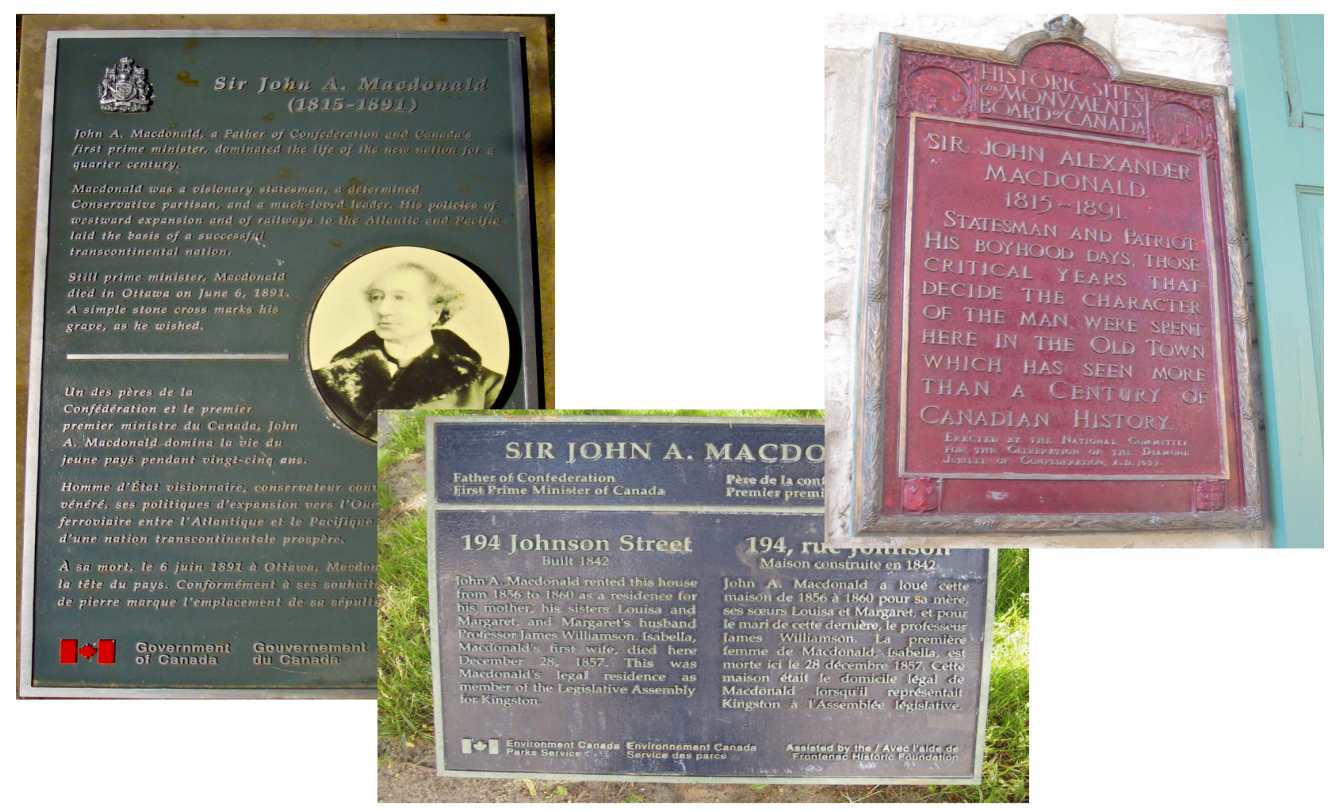

Figure 2. Plaques at Macdonald gravesite (Cataraqui Cemetery), 194 Johnson Street, and 112 Rideau Street. (Photos credit: Laura Murray).

As the bicentennial of Macdonald's birth approached, ample resources were devoted to making his presence even more emphatic in Kingston. In addition to $\$ 360,000$ for public service messages on Macdonald, Heritage Canada granted \$511,000 to the Sir John A. Macdonald Bicentennial Commission, based in Kingston under the leadership of former Stephen Harper speechwriter Arthur Milnes, and its Salon Theatre Company (Boswell, 2013). The City of Kingston committed, all told, $\$ 329,000$ to the bicentennial. ${ }^{8}$ The commission's ambitions were grand, including a cross-Canada train trip with "leading statesmen [sic], academics, artists and entertainers to deliver Macdonald-themed programs to communities along the way." In the years leading up to 2015, Salon Theatre put on a musical by the name Sir John Eh?, and the In Sir John A's Footsteps walking tour was ramped up, complete with various former prime ministers and media celebrities brought in to host. The commission intended to build a Macdonald library, educate school children, and make a "superb bilingual website and database" complemented by a mobile app on "the cutting edge of 21 st century technology." The commission told the City Council in 2013 that "expenditures through 2017 are expected to total several million dollars" (Funding Request to Kingston City Council: Introduction, 2012, p. 201, 211, 203).

\footnotetext{
${ }^{8}$ Some of this expenditure was later defrayed by the Department of Canadian Heritage in the amount of $\$ 170,000$. See Beach (2015), February 17, p. 86.
} 
When one of the Heritage working groups was presented with the draft of the new plaque to go beside the Macdonald statue, I was so upset. All the way through, Macdonald was referred to as "John" or "Sir John A.," and that made me furious. To me it's a term of cheeky chummy tribute, like "Dief the Chief," or "the tiny perfect mayor"-what they used to call David Crombie in Toronto. In the section about Macdonald's legacy, and I printed this out today to check my memory of it, he was described as "a unique personality, warm communicator, consensus builder, creative thinker, and leader." "At the national level," it read, "Sir John A. is idolised as the 'Father of Confederation,' the defender of the national economy, and the integrator of the new nation by a national railroad."

I just kind of flipped at that. Who's doing the idolising? You know I'm an English prof, and when I see the passive voice, that "is idolised," I think, okay tell me, who's doing the deed? Don't hide it. Well, it isn't all of us. So I pushed to get that changed. The interesting thing is, though, in terms of confrontation, that I did soften as I went. I knew it was just going to be impossible to get anything on there about genocide or even starvation...so I just made sure they got rid of the "Sir John A." stuff and the idolatry, and got this really pathetic little sentence in: "Many things have changed since his time in office, but many of the institutions and challenges of today's Canada have their roots in his tenure as Prime Minister." To me, and to people already aware of anticolonial struggle, this sentence might be a trigger; it might look like an acknowledgment of the ongoing colonialism of the Indian Act and so on. But it's hardly a real acknowledgment. It wouldn't inform anybody who didn't already know about the history of Indigenous dispossession and abuse. I'm kind of embarrassed about the whole thing.

- Laura Murray

The commission and its associates have tended to alternate between awe and jovial affection in their representations of Macdonald (Dutil, 2015; Milnes, 2015; Milnes, 2014). They have generally responded to discussions of his colonialist legacy by hastening to acknowledge his penchant for drink and his wily political feints and tricks (Briibassi, 2011; Milnes, 2015; Deachman, 2015). But we would suggest that this "good old boy" talk functioned as a smokescreen to avoid discussing or even perceiving the human cost and colonial imperative of Macdonald's time in office.

Despite their resources and insistent efforts, the Bicentennial Commission did not have a lock on representations of Macdonald. In January 2013, just before the official announcement of federal funding for the bicentennial, the words "This is Stolen Land," "Murderer," and "Colonizer" appeared on the base of the Macdonald statue in City Park, which was splattered with red paint. Another Macdonald plaque also was splashed with red. 
The paint was cleaned off quickly, but not forgotten (Vandenbrink, 2013; Kennedy, 2013). ${ }^{9}$ When we have in mind a man who (in the words of plaques to his honour) was "the political genius of Confederation" at "the centre of public life for fifty years," who "presided over the expansion of Canada to its present boundaries," and under whose administration "a transcontinental railway built and settlement of the west encouraged," it is not only activists who are likely to perceive connections to colonial aggression. ${ }^{10}$ In May 2014, the Canadian Historical Association bestowed the

Sir John A. Macdonald Prize for

Canadian History on James

Daschuk's Clearing the Plains:

Disease, Politics of Starvation, and the Loss of Aboriginal Life (2013), which features a meticulous account of the genocidal effects of Macdonald's Indian policies. At Queen's University, the annual Symposium on Indigenous Research in November 2014, two months before the bicentennial birthday, was
I hear from city-sponsored surveys and on the streets, "enough of Sir John A." We know his story; now let's start hearing of the other stories here in Kingston, such as the First Nations and immigrant story. Let's also recognize this is traditionally shared territory between the Anisinaabe and Haudenosaunee peoples. Before the Mohawks were granted territory from the British, the HuronWendot, Mississaugas, Algonquin, Mohawks and Oneidas all traveled, hunted and fished through this territory.

- Paul Carl devoted to understanding the colonial legacies of Macdonald and his government. The Gertrudes, a local band, released a song and video "Of One Almighty Nation," which takes a critical perspective on Macdonald (Khan, 2015). And PhD student Erin Sutherland was gearing up as curator of Talkin' Back to Johnny Mac, a series of artistic interventions on Macdonald's colonial legacy to take place in public spaces, including the Macdonald statue, in winter and spring 2015 (Kerr, 2015). Meanwhile, the City of Kingston, through its Cultural Services division, was beginning to take steps to recognize and collaborate with Indigenous projects and people and to revise its policy about commemorative installations and activities (Beach, 2014; Beach 2015). ${ }^{11}$

\footnotetext{
${ }^{9}$ More recently, on Macdonald's birthday in January 2016, protestors burned an effigy of Macdonald beside his statue during a commemorative ceremony (Lea, 2016).

10 Wording is from plaques located at 112 Rideau Street, Kingston, and beneath another Macdonald statue at the south end of Queen's Park, Toronto.

${ }^{11}$ Although the initial mandate was to simply clarify policy about commemoration, it became clear from public consultations and a working group strategy that there was strong interest among city residents in more information and commemoration of Indigenous history, and this is reflected in the final report and polices that emerged.
} 
By the time 2015 rolled around, the Macdonald Commission had disbanded, for reasons and on terms that have not yet been publicly explained. Some of its money and responsibilities were left in the hands of Salon Theatre, and younger employees seemed to take the lead. In the end, and at the last minute, some small space was made for critical perspectives during the birthday week. The birthday dinner happened - and the visit by Prime Minister Stephen Harper, the debate about whether Macdonald was Canada's greatest prime minister, and the séance. But piggybacking on initiatives out of Queen's University, Salon Theatre also co-sponsored visits to Kingston by David Garneau, a Métis artist who did a harrowing performance as Louis Riel at the Macdonald Sculpture, and James Daschuk, who spoke with cool certainty about the deadly effects of Macdonald's policies on the peoples of the plains in the 1870s and 1880s. Daschuk and Garneau's joint event, preceded by a drum group, drew a standing-room only crowd and provoked a weighty question and answer session in the very church Macdonald attended. ${ }^{12}$ In the national media, critical and celebratory views aired alongside each other. ${ }^{13}$

\section{Marking the Territory: Indigenous Traces and Possibilities}

As the above discussions would suggest, Kingston's strong sense of itself as a "heritage" city has produced a large number of plaques commemorating not only heritage buildings and Sir John A. Macdonald but also architects, military leaders, religious leaders, business leaders, and other powerful white men of the nineteenth century. Kingston is sometimes said to be "cluttered" with plaques, and even people who would like to see other histories and residents remembered have suggested we should not add any more. Plaques are seen as old-fashioned in the era of mobile apps and q-codes and performance art. It's often said that nobody looks at them and they are not an effective way of engaging the public.

But we feel that plaques claim and label territory with an authority that other media don't manage. They are performances, too, and they perform and speak over and over when nobody is around. To erect plaques that have anticolonial stories written on them is a kind of appropriation of colonial authority. And Indigenous and non-hegemonic experiences of history deserve just as much permanence and resilience as white and colonialist versions of history. It

\footnotetext{
12 For a general listing of events, see Lea (2015). For the Garneau/Daschuk event, see McBay (2015).

13 For example, Richard Gwynn, "Sir John A. Macdonald, the greatest PM of all” and Laura Murray, "Sir John A. Macdonald: Nation builder or racist?" both appeared in the Toronto Star, January 9, 2015. The same day, Prime Minister Stephen Harper offered a tribute to his predecessor in the National Post, which also published "Raise a glass to Sir John A." by Father Raymond J. deSouza; but the Ottawa Citizen published Laura Murray, "Let's do what Macdonald didn't," and Niigaan Sinclair, "Stop apologizing for John A. Macdonald." Among many critiques of Macdonald in other media outlets, see also Marche (2014).
} 
would seem like bad timing if, just at a political moment that may permit the assertive countering of white settler narratives, the City were to say, "sorry, we're not doing plaques any more."

Mindful that the City of Kingston was about to develop a new commemoration policy, and frustrated with what we were seeing and not seeing on the city's streets, we decided to try

It seems to me that if something is cast in bronze - the words there have been put into metal, they're hard - they're going to be there. As we've seen you can put red paint on it, you can vandalize it, but it's even more permanent than a book. You can't rip it apart; it's there. It marks a claim on the land, like the flags explorers used to plant. Some people say plaques are kind of old-fashioned, and we should be doing new things online, but I say, if all those plaques are there, now, that are so permanent-looking and actually permanent, that are telling an incomplete story-both in the sense that it's only about some people, and also in the sense that it doesn't even tell everything about those people - then we have to respond by taking some of those away, and adding other ones that tell other stuff. You should be able to read these other stories off the surface of the city.

- Laura Murray to imagine some new plaques for Kingston, "talking back" to official histories along with the art performances curated by Erin Sutherland. Some of the plaques we propose here are proposals that we could imagine the City itself embracing and installing in bronze. Others are concepts that would be more suited to artistic development or performative temporary installation - or maybe just to contemplation of the effect they would have if they were in fact erected.

But before considering new ways of marking Indigenous history in Kingston, it is important to note that indigeneity is not entirely absent from this landscape. The Indigenous name for this place now known as Kingston is Katarokwi, or as the French wrote it, Cataraqui. That word is all around

us every day as the name of a river, a mall, a soccer team, an arena, a golf club, a dental centre, a recreational trail, and any number of other businesses, places, and organizations. We might go out to the "Cat Centre" to pick up a pair of shoes or up to "Little Cat" for a hike. So every day we have occasions to remember Indigenous occupation of this land. And yet people don't often read the word Cataraqui as Indigenous, any more than they think twice about other nearby Indigenous place names such as Gananoque ("Gan" to locals), Deseronto, or Napanee. It would be wonderful, for example, to undertake an initiative in the vein of Hayden King and Susan Blight's Ogimaa Mikana Project, in which rewritten street signs have reminded Torontonians of the Anishinaabemowin origins of familiar roads and their names (AndrewGee, 2015; Ogimaa Mikana Project 2013-). 
At present, the only self-explanatory permanent physical markers of Indigenous presence in Kingston are the several plaques about Molly Brant, Konwatsi'tsyayén:ni, who was granted land here after the American Revolution and was buried in the cemetery of St. Paul's Church. A plaque in Brant's honour near the site of her house is written in English, French, and Mohawk - the only instance of an Indigenous language inscribed in public that we know of in Kingston. In fact, the Brant plaques also may be the only ones in the city to honour a woman.

And there is one more permanent physical assertion of Indigenous presence we know of in Kingston. Just off Montreal Street, the Belle Park golf course entrance is marked by a forty-one foot totem pole. Our inquiries revealed that inmates at Joyceville Institution designed and carved it from a cedar pole sent by the Union of British Columbia Chiefs, and the Native Brotherhood gave it to the City of Kingston in 1973 to mark its tercentenary. ${ }^{14}$ Charles Hill, a Mohawk inmate, spoke at the unveiling. "We do not celebrate 300 years - that is yours," he said, and reminded those present that the Iroquois confederacy dated back to 1450. He also noted that Algonquin peoples cooperated with the French when they came in 1673 to build a fort here. "We hope this totem pole will create an awareness that there are not only reasonable people in jail, but reasonable Indians outside of jail," he said, and stated that "we want [the pole] to say to everyone who sees it that we desire brotherhood" (Totem pole reflects desire for brotherhood, 1973). ${ }^{15}$ The pole was installed at the entrance to the new golf course that the City of Kingston opened on a former landfill, known first as Cataraqui Park, and now as Belle Park.

Sadly, today, the pole does not say very much to most who see it. It is dilapidated, and there is no marker stating where it comes from, which probably leads many to think that it is some bit of fake Indian kitsch. Perhaps that is what the city thought when it used chain saws to cut down two other inmate-carved poles in Lake Ontario Park a few years ago. But those poles were rescued by the Katarokwi Native Friendship Centre, and recently restored by Aboriginal inmates at Frontenac and Pittsburgh Institutions (St. Joseph's Catholic School, 2014). Also, in the years since 1973, Indigenous graves were discovered by archaeologists on Belle Island which lies at the outer end of Belle Park. The bones were disinterred but have since been reburied. Negotiations are ongoing between the City of Kingston and representatives of Anishinaabe and Haudenosaunee communities about how the Island will be

\footnotetext{
14 Thanks to Paul Robertson, David St. Onge, and John Jansen for leads on the origins of the pole. The carvers were Tim Boyer, Clifford Beaucage, Donald George, Charles Hill, Arnold Jons, Peter Jones, Wayne Mallette, James Peters, and Clarence Southwind (Carving a creation of 9 Indian inmates, 1973).

15 These poles now stand on the grounds of Correctional Services buildings off Sir John A. Macdonald Boulevard.
} 
managed. So perhaps there will be some appropriate synchronicity and Belle Park and Belle Island can be known as Indigenous spaces (Ontario Ministry of Municipal Affairs and Housing, 2015; Thurston, 2006).

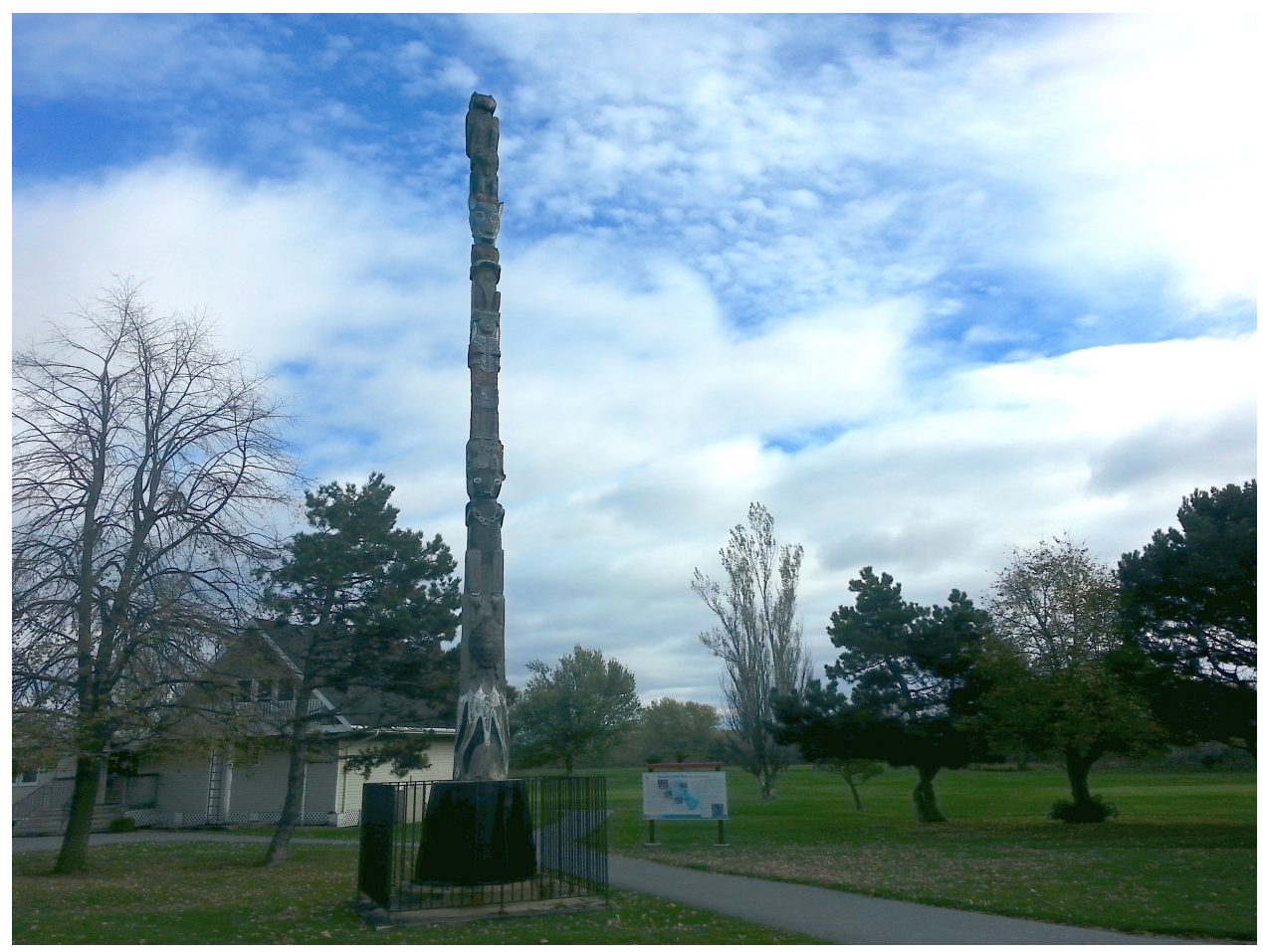

Figure 3. Belle Park totem pole made by Indigenous inmates at Joyceville Institution ca. 1973. (Photo credit: Laura Murray).

Apart from these three examples - the name Cataraqui, the Molly Brant plaques, and the Belle Island totem pole-Kingston is quite bereft of physical markers of Indigenous presence.

In the following section, we would like to propose a few more.

\section{Dr. Peter Jones / Kahkewaquonaby (1843-1909)}

In 1866, Peter E. Jones, or Kahkewaquonaby, became one of the first Indigenous people to obtain a degree from a Canadian university when he graduated from Queen's University medical school. Jones was the third son of the Mississauga-Ojibwe missionary Peter Jones and his English wife Eliza Field (Sherwin, 2012). Influenced by his father's interest in traditional Indigenous medicine, he completed a thesis at Queen's entitled "The Indian Medicine-Man." It would surely have been quite a statement for him to choose such a topic at a time when the medical establishment usually dismissed these practices and 
treatments as mere superstition. But Jones evidently did not shy away from insisting on his Anishinabe identity, as he used his Anishinabe name in his official registration at Queen's. Unfortunately, no copy of the thesis survives. After graduation, Jones returned to his home with the Mississaugas of the New Credit near Brantford, Ontario, and was elected chief and band doctor. As secretary to the Grand Indian Council of Ontario, he conveyed the chiefs' concerns to Prime Minister Sir John A. Macdonald, most importantly during consultations on the Indian Act - without success, it must be added, but with great diligence and sincerity. Macdonald's Electoral Franchise Act of 1885 did permit some Indians to vote, and Jones actively campaigned for its passage. ${ }^{16}$ That same year, Jones established and edited Canada's first Indigenous newspaper, The Indian, with a central goal of encouraging Indigenous people to use the vote they had been granted. ${ }^{17}$ Appointed a Federal Indian Agent, a post usually reserved for white settlers, Jones defended hunting rights, promoted education, and introduced public health measures on his reserve.

Other than being Indigenous, Dr. Jones is the perfect "plaqueable" community leader according to Kingston's conventions of noting the achievements of educated Protestant men, and he is even connected to Sir John A. Macdonald himself. An acknowledgment of his achievements would appear to be a very uncontroversial addition to the bank of plaques in front of the old Kingston General Hospital building where he did his training.

\section{The Prison for (Indigenous) Women}

Dr. Jones's achievements notwithstanding, we want to challenge the idea that only people with high position are worthy of memorialization. As Charles Hill said in 1973 at the unveiling of the Belle Park totem pole, the inmates of Kingston's prisons are residents of Kingston too. For almost two hundred years, Kingston has been a national centre of incarceration. From 1835 to 2013 the Kingston Penitentiary operated here, and from 1934 to 2000 the Prison for Women was located in Kingston, which until 1995 was the only federal penitentiary for women in Canada. Kingston still hosts the Ontario headquarters of Correctional Services Canada and the Millhaven, Collins Bay, Joyceville, and Bath Institutions.

Prisons are a living part of Sir John A. Macdonald's legacy, since Macdonald's Indian Act was the administrative mechanism that produced a wide range of social fracture and poverty among Indigenous people. While Indigenous people make up about $4 \%$ of the

\footnotetext{
16 The Liberal government repealed this law in 1898. See Moss and Gardner-O'Toole (1987); Bartlett (1980); and Montgomery (1965).

17 The newspaper lasted only one year. See Sherwin (212, pp. 103-120).
} 
Canadian population, as of February 2013, 23.2\% of the federal inmate population is Indigenous. Indigenous women are even more overrepresented in the federal correctional system, representing 33.6\% of all federally sentenced women (Office of the Criminal Investigator, 2013). Many Indigenous offenders are denied their ceremonies, which would help them heal. Many are imprisoned far from their home territories, thus isolated from their culture and community even more. The high rate of incarceration for Indigenous peoples has been linked to systemic discrimination and attitudes based on racial and cultural prejudice, as well as to the intersecting effects of the residential school system, of dislocation and dispossession resulting from colonial policies, and of poverty. ${ }^{18}$ We note too that the Indigenous carceral experience is part of an even broader history of racialized violence in the form of policing and incarceration; currently, rates of Black male incarceration, in particular, are rising in Canada and are already higher per capita than they are in the United States (Rankin \& Winsa, 2013).

Kingston's two oldest prison buildings currently stand, empty, on (wait for it) Sir John A. Macdonald Boulevard: at the lake end, Kingston Penitentiary, and a little to the north, the Prison for Women (P4W), built by inmates at Kingston Penitentiary. Much research needs to be done to add a human element to the various government reports written in and on these prisons over the years. ${ }^{19}$ Whatever their future use, the empty buildings need cleansing, and this could have various aspects including art and ceremony. Passers-by should also understand something of the facts of the use of the buildings. Macdonald's law office at 343 King Street East is marked by a Parks Canada plaque. Let us also mark the law as it has been experienced by incarcerated Indigenous people.

The figure below is an initial attempt at a plaque that might belong in front of the Prison for Women building. ${ }^{20}$

\footnotetext{
18 Even the highest court in Canada has acknowledged this reality. See R. v. Gladue (Supreme Court of Canada, 1999) and R. v. Ipeelee (Supreme Court of Canada, 2012)..

${ }^{19}$ Margaret Little, Jackie Davies, and Janice Hill at Queen's University are embarking on a history project about Indigenous women's experiences of P4W. We look forward to the results of this project and to various other Indigenous performative, ceremonial, or community projects about these spaces, whatever ends up happening to the buildings themselves.

20 Sources for the plaque text include the following from the Correctional Service Canada (2008) and (1990), the latter of which is a remarkable qualitative study by two Indigenous former inmates, See also Pollack, (2008, p. 6) and Solicitor General of Canada (1996; the "Arbour Report"). The Arbour Report constitutes a comprehensive and damning view of $\mathrm{P} 4 \mathrm{~W}$, and contains considerable specific discussion of what it names as "racism in criminal justice institutions" (5.2.5) and Indigenous women's particular circumstances and experiences: "If the history of women's imprisonment is one of neglect and indifference, it will come as no surprise that the history of Aboriginal women's imprisonment is an exaggeration of the same" (4.3.1). See also Public Safety Canada (2012).
} 


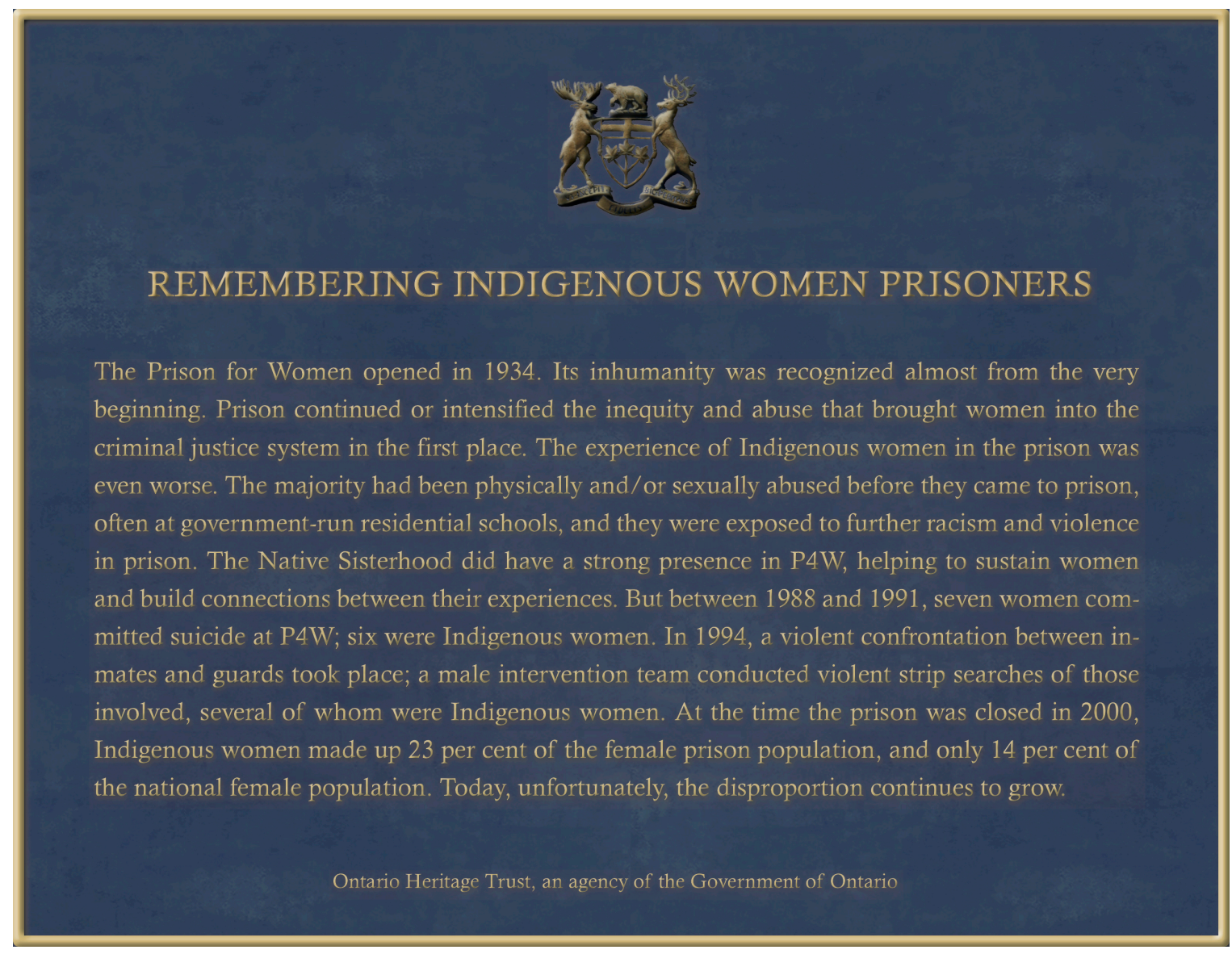

Figure 4. Proposed plaque for the Prison for Women site. (Credits: Text by Laura Murray and Paul Carl; Design by Teresa Carlesimo).

\section{Indigenous People and Schooling}

In 2012, the Limestone District School Board decided to name its new school in Kingston East "École Sir John A. Macdonald Public School." Board member Elaine Crawford was happy with the decision. "Trustees were conscious to choose a name that reflects our city and our school communities," she said, "and we have it" (John, 2012). In 1883, Sir John A. Macdonald authorized the creation of Industrial/Residential Schools in the Canadian west. In the words of the Truth and Reconciliation Commission,

These residential schools were created for the purpose of separating Aboriginal children from their families, in order to minimize and weaken family ties and cultural linkages, and to indoctrinate children into a new culture - the culture of the legally dominant Euro-Christian Canadian society, led by Canada's first prime minister, Sir John A.

Macdonald. (Truth and Reconciliation Commission, 2015)

The TRC report further quotes Macdonald speaking in parliament in 1883: 
Indian children should be withdrawn as much as possible from the parental influence, and the only way to do that would be to put them in central training industrial schools where they will acquire the habits and modes of thought of white men. (Truth and Reconciliation Commission, 2015; v, 2)

TRC investigations over the past several years have documented with unflinching detail the violence, cruelty, and soul-destruction that those schools produced.

There are probably hundreds of schools named after Macdonald across Canada. But to newly choose such a name just at the time when public awareness about residential schools has finally begun to rise is a bit bizarre. Students at this school especially ought to be taught about Macdonald's role in residential schooling of Indigenous children - and if teachers, students, or parents feel uncomfortable about that it would be a sure sign of the inappropriateness of the name.

But in imagining a plaque for this site, we took another tack. When Macdonald School opened in 2013, one year late because of construction delays, Kingston East parents were incensed. That reminded us of another long-term effect of the Macdonald era on Indigenous education: the way services on reserves are not adequately funded. One particularly notorious story is the situation at Attawapiskat First Nation in northern Ontario, 2100 kilometres north of Kingston. The facts are stark. Attawapiskat's J.R. Nakogee School opened in 1976. In 1979, 30,000 gallons of oil leaked into the soil near the school. Health problems were identified right away, but the school was not closed until 2000. Time and again, the federal government promised a new school, but it never happened. In 2008, Shannen Koostachin started campaigning for a new school; she was only thirteen years old. Minister of Indian Affairs Chuck Strahl told her that the government did not have the money for a new school, and Shannen and her community stepped up efforts on social media, travelling to Ottawa, and mobilizing national support. In 2009, the contaminated school was finally torn down. In 2010, while travelling the 600 kilometres it took for her to get to high school, Shannen was killed in a car accident. A few months later, money was approved for a new school (Shannen's Dream, 2010-). Shannen never saw the Kattawapiskak Elementary School that opened in July 2014. But today, the organization Shannen's Dream continues to fight for safe schools on reserves, and for culturally based education of Indigenous children.

Attawapiskat children had to live with a contaminated school for twenty-one years, and no school at all for fourteen years, whereas Kingston East children had to be bused to another school ten minutes away for one year while their new school was finished. We imagined a plaque about Attawapiskat and Shannen Koostachin for location at Macdonald School because 
the comparison might help Kingston students bring the legacies of Macdonald's policies in touch with their own experience. ${ }^{21}$

\section{The Spirit of Sir John A.?}

In front of Kingston's City Hall, where train tracks once ran, stands a splendid shiny black steam engine number 1095. It was made in Kingston, and boasts a multi-page "bookstyle" plaque explaining its history. Although it is not in any way associated historically with Sir John A. Macdonald - it postdates the Last Spike and Macdonald's trip by train to the west - the Junior Chamber of Commerce who donated it to the city in 1976 decided to christen it "The Spirit of Sir John A." and to inscribe this name in flowing gold script on its side.

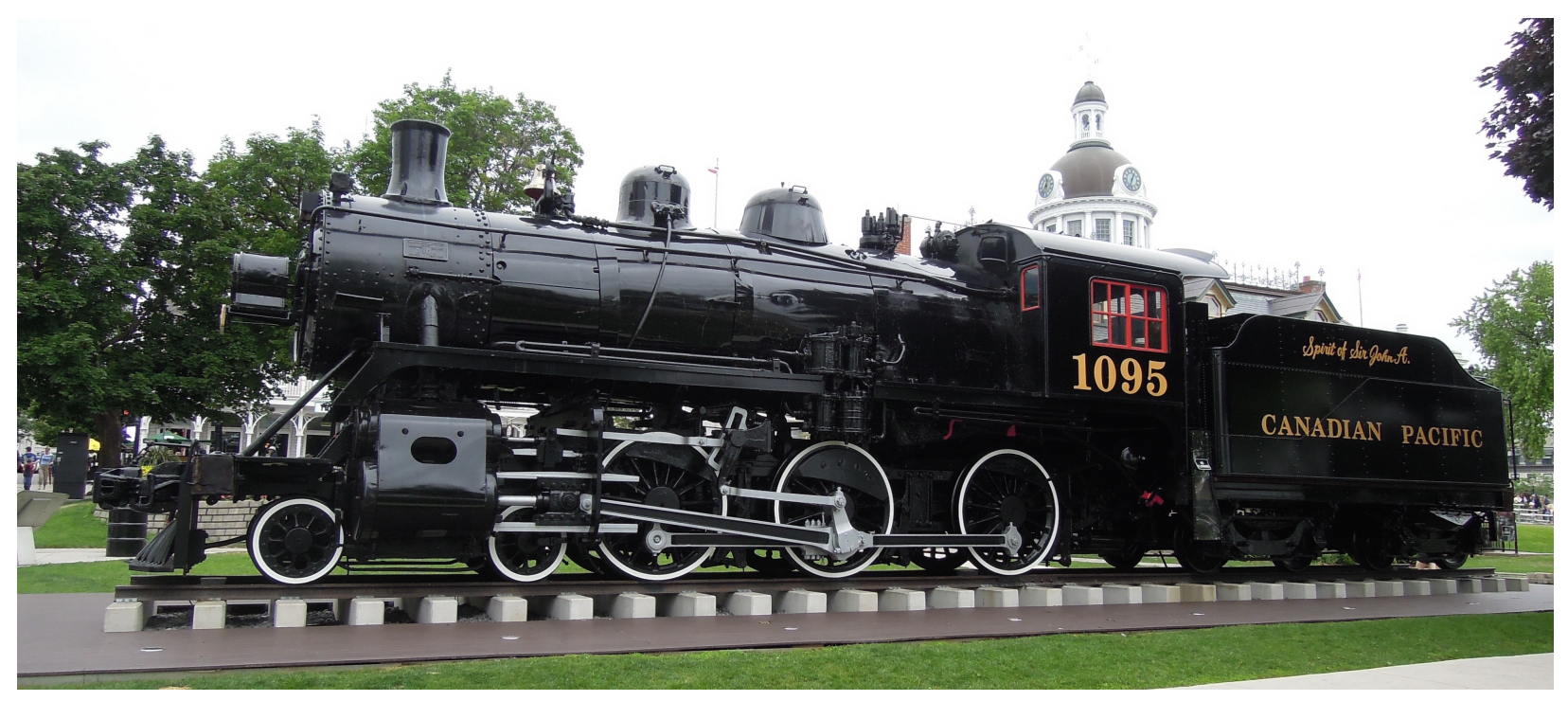

Figure 5. Engine 1095, known as "The Spirit of Sir John A.," Kingston, Ontario. (Photo credit: Laura Murray).

In what ways did the railway manifest "The Spirit of Sir John A."? To many, that phrase evokes westward expansion, the growth of an agricultural economy, and the population of the west with immigrants. To Kingston in 1976, at a time when factories had been shuttered and the city's future did not look especially bright, Macdonald stood for courage, vision, and persistence.

We think today of a darker spirit. Our plaque might read like this:

${ }^{21}$ In 2015, the Limestone District School Board decided to name its next new school after Molly Brant. It remains to be seen what sort of marking or interpretation will accompany this name. See McKay (2015). 


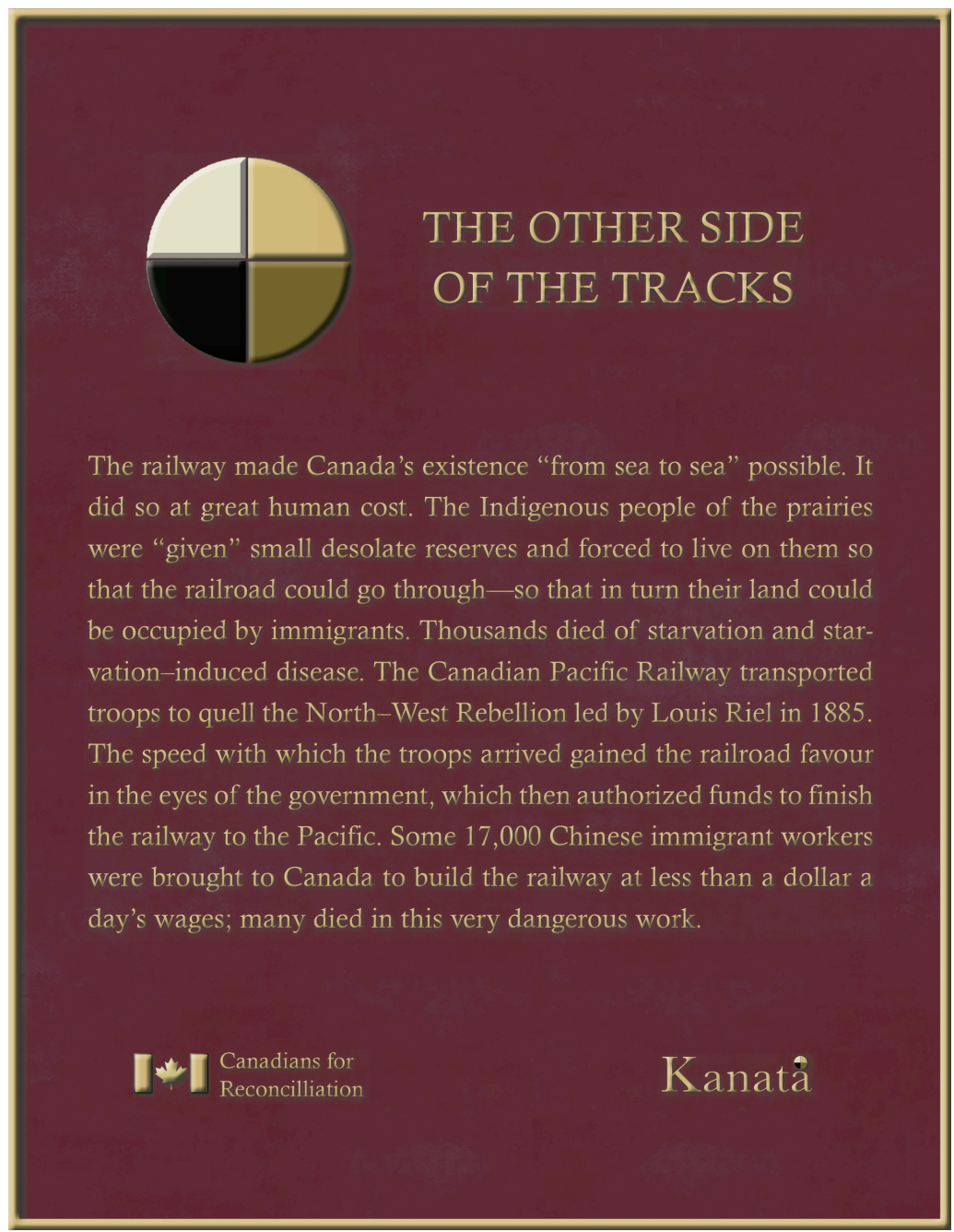

Figure 6. Another take on the "Spirit of Sir John A." (Credits: Text by Laura Murray and Paul Carl; Design by Teresa Carlesimo).

\section{Conclusion}

Of the two of us, Laura gets more impatient with the lingering glorification of Macdonald than Paul does. She finds it constantly stressful to face Macdonald's presence, and she found writing up this paper to be stressful as well. She tends to be pessimistic about the possibility that white settlers will ever really acknowledge colonial history for what it is. But Paul points out that the public everyday coexistence of different perspectives on Macdonald would mirror the fact that Indigenous and non-Indigenous people have to live side by side even though they often do not agree. The two-row wampum gives him a patience and philosophy that can tolerate distinct perspectives and assert survival and sovereignty (see Kelsey 2014). Writing this essay has been a fruitful collaboration for both of us as we have been moved to assert the importance of these symbolic battles, but also to acknowledge that 
they are in some sense "only symbolic," and are a tiny part of the struggle for Indigenous justice today. We both hope that as the focus on Macdonald and his legacy fades after the big birthday, and as Canada takes up the challenge of the Truth and Reconciliation Commission, there will be new Indigenous experiences to mark and document and assert in new ways.

We have a very diverse community here among First Nations people. We have people who just go about their lives, like I did when I was younger, and may not even say they're Native. We have people who are very militant, who stand up, and say, this is wrong. Sometimes that works. Myself, I feel that if you teach someone, you teach them for a lifetime. If you upset someone, they're upset for ten minutes, and then they forget. So that's my approach, teaching.

I want people to be proud of who they are. I'm proud to live in the city of Kingston and what they've done over the past years. I always say it's like a public school dance, with the boys on one side and the girls on the other and nobody wants to start the dance; they're afraid to start this dance. But some of us under the guidance of those who have been doing it longer stepped up and said, it's time to work with the city... In the committees and boards I sit on, I try to be a role model, especially to the young men, and to say, "they're not against us, let's work with them." People talk about assimilation. But I don't look at the City as assimilating us; I think we're assimilating the City. They are starting to understand that we have that two-row wampum belt and we walk alongside them and we're equals, and I really do believe that is starting to work.

The City has a talking stick that was gifted by the Aboriginal community in June 2011. This year, the City completed the first phase of a dialogue and relationship-building exercise. National Aboriginal Day has become a regular event to recognize the connection between Kingston and the First peoples. On June 2015 the City adopted an acknowledgment to be read at the beginning of every city council and committee meeting.

I would like to see a Council made up of elders and traditional people that guides City Council on First Nations issues. I would like to see a staff person within the city who focuses on First Nations issues. I'd like to see more of the history before Kingston I'd like to see the history of the First Nations people before contact, during contact, and continuing on.

-- Paul Carl

The Macdonald Bicentennial Commission thought of Abraham Lincoln as a comparator for Sir John A. Macdonald; they wanted to draw tourists here just as Springfield Illinois did during Lincoln's bicentennial birthday in 2009 (2012, p. 192). Lincoln and Macdonald are of the same generation, and comparable in terms of their intense commitment to the idea of nation. But the similarities may end there - and in any case, tourists didn't flock to Kingston during the Macdonald bicentennial. A comparison to Robert E. Lee, commander of the Confederate Army in the US Civil War, might be more suggestive. As he pondered the 
fate of New Orleans monuments to leaders of the confederate cause in July 2015, Mayor of New Orleans Mitch Landrieu said that there is a difference between remembrance and reverence. Monuments and plaques tend to encourage reverence, either by their design and content or by their very genre or form. But they can be experienced as violence by those whose oppression they celebrate. In his discussion of whether to remove four prominent confederate monuments, Mayor Landrieu said the debate was "not about these individual historic figures but about the broader context of the monuments themselves, how they fit into our history, and how they inspire us or don't, today" (2015). He invited City Council to imagine a young African-American girl looking up at the General Lee statue, and wondering what kind of city she lived in, and where she fit into it. He said, "we should not look away from our history; rather this is about fully reckoning with our past." And thus, he concluded, the monuments should not occupy "places of reverence," but rather museums, where they can be part of an educational context, not a celebratory context. "Remembrance, yes," he said; "reverence, no" (Landrieu, 2015).

When they asked me to participate on Macdonald's birthday this year, I thought, "oh boy, what do I do? What do I do?" But I thought, and what I said was, "I'm not here to celebrate this person. I'm here to remind you that your celebration of your first Prime Minister is happening on First Nations territory." That's the way I could participate. Conversation I can do. Not celebration.

- Paul Carl

It is this distinction between remembrance and reverence we urge upon Kingston. As Prime Minister and Minister of Indian Affairs, Macdonald knowingly presided over policies that led to the deaths of thousands of Indigenous people on the prairies in the 1870s and 1880s. Without Macdonald, we may well not have had Canada, but we also would not have had the Indian Act, Residential Schools, the numbered treaties, the national railway, and the social and cultural violence produced by the legal, administrative, and physical infrastructure of a colonial nation. If we are going to remember Macdonald and not just revere him, those legacies also have to be marked in our streets and in our hearts.

\section{References}

Andrew-Gee, E. (2015, June 2). Toronto street signs a reminder of First Nations heritage. Toronto Star. Retrieved from https://www.thestar.com

Bartlett, R. (1980). Citizens minus: Indians and the right to vote. Saskatchewan Law Review, $44,13-25$. 
Beach, C. (2015). City of Kingston, Report to Arts, Recreation and Community Policies Committee (Report No. ARCP-15-008). Retrieved from the City of Kingston website: https://www.cityofkingston.ca/documents/10180/9818613/ARCP A0615008.pdf/a30f0b76-baea-4176-ad81-26087bad705c

Beach, C. (2014). City of Kingston, Information Report to Council (Report No. 15-004).

Retrieved from the City of Kingston website: https://www.cityofkingston.ca/documents/10180/7589760/COU_A031515004.pdf/688b8420-71db-4b90-920b-c5cd4f5d4ba8

Beach, C. (2015). City of Kingston, Report to Council (Report No. 15-178). Retrieved from the City of Kingston website: https://www.cityofkingston.ca/documents/10180/8271040/COU_A081515178.pdf/f44c76ab-03db-4324-bbe6-f0d983fd22a5

Black History. Stones. Retrieved from: http://www.stoneskingston.ca/black-history/

Boswell, R. (2013). Moore to announce \$870K kickoff to Sir John A.'s 200th birthday. Postmedia News. Retrieved from http://o.canada.com

Brijbassi, A. (2011, April 22). A patriotic visit to Kingston as the 2011 Canadian election nears. Toronto Star. Retrieved from https://www.thestar.com

Carving a creation of 9 Indian inmates. (1973, July 30). Kingston Whig-Standard.

City of Kingston. (2010). City of Kingston Culture Plan. Retrieved from https://www.cityofkingston.ca/documents/10180/14469/Plan_KingstonCulturePlan_20 10.pdf/e5a2c4ec-3de7-4186-b533-32b8b1061ce4

Correctional Service Canada. (2008). The closing of the prison for women in Kingston. Retrieved from the Department of Justice Canada website: http://www.cscscc.gc.ca/text/pblct/brochurep4w/12-eng.shtml

Correctional Service Canada. (1990). Creating choices: the report of the task force on federally sentenced women. Retrieved from the Department of Justice Canada website: http://www.csc-scc.gc.ca/women/toce-eng.shtml

Correctional Service Canada. (1990). Survey of federally sentenced Aboriginal women in the community. Retrieved from the Department of Justice Canada website: http://www.csc-scc.gc.ca/publications/fsw/nativesurvey/toce-eng.shtml

Deachman, B. (2015, September 30). Conrad Black leads Sir John A. walking tour to a pub, and the old PM would have approved. National Post. Retrieved from http://news.nationalpost.com

De Souza, R. J. (2015, January 9). Raise a glass to Sir John A. National Post. Retrieved from http://news.nationalpost.com 
Dutil, P. (2015). Remembering Sir John A. means remembering who we are. iPolitics. Retrieved from http://ipolitics.ca

Gwynn, R. (2015, January 9). Sir John A. Macdonald, the greatest PM of all. Toronto Star. Retrieved from https://www.thestar.com

Harper, S. (2015, January 9). Stephen Harper reflects on Canada's first Prime Minister, Sir John A. Macdonald. National Post. Retrieved from http://news.nationalpost.com

Jansman, A. (2015). Planning a birthday party for Sir John A. Queen's Alumni Review, 4. Retrieved from http://www.queensu.ca/gazette/alumnireview

John, R. (2012, February 9). New school in Kingston named by Limestone District School Board. Kingston Herald. Retrieved from http://kingstonherald.com

Kelsey, P. M. (2014). Reading the Wampum. Syracuse, New York: Syracuse University Press. Kennedy, P. (2013, January 21). Vandals hit Sir John A. again. Kingston Whig-Standard. Retrieved from http://www.thewhig.com

Kerr, M. (2015, January 9). Rethinking Macdonald. Queen's Gazette. Retrieved from http://www.queensu.ca/gazette/stories/rethinking-macdonald

Khan, S. (2015). The Gertrudes - Of one almighty nation. [Video file]. Retrieved from https://youtu.be/KEQ whr1zBM

Landrieu, M. (2015, July 9). Watch Mitch Landrieu's Confederate monuments speech to the City Council. [Video file]. Greater New Orleans Times-Picayune. Retrieved from http://www.nola.com/politics/index.ssf/2015/07/watch_mitch_landrieus_confeder.html

Lea, M. (2015, January 4). Events honour, celebrate Sir John A. Kingston Whig-Standard. Retrieved from http://www.thewhig.com

Lea, M. (2016, January 11). Macdonald revered, reviled at Kingston ceremony. Kingston Whig-Standard. Retrieved from http://www.thewhig.com

Marche, S. (2014, December 14). Old Macdonald. The Walrus. (January/February 2015). Retrieved from http://thewalrus.ca/old-macdonald/

McBay, A. (2015, January 12). Métis art and Macdonald history draws standing-room only audience. Kingston Heritage. Retrieved from http://www.kingstonregion.com

McKay, J. (2015, June 17). New school named after Molly Brant. Kingston Whig-Standard. Retrieved from http://www.thewhig.com

Milnes, A. (2014, May 25). Come home to Kingston. Kingston Whig-Standard. Retrieved from http://www.thewhig.com

Milnes, A. (2015, January 22). Many supporters made Macdonald Bicentennial special. Kingston Whig-Standard. Retrieved from http://www.thewhig.com 
Milnes, A. (2015, January 9). Sir John A.: Get ready to celebrate. Kingston Whig-Standard. Retrieved from http://www.thewhig.com

Montgomery, M. (1965, March). The Six Nations Indians and the Macdonald franchise. Ontario History, 57(1).

Moss, W., \& Gardner-O'Toole, E. (1987). Aboriginal people: History of discriminatory laws. Retrieved from Government of Canada Publications website: http://publications.gc.ca/Collection-R/LoPBdP/BP/bp175-e.htm

Ontario Ministry of Municipal Affairs and Housing. (2015). Municipal-Aboriginal Relationships: Case Studies. Retrieved from http://www.mah.gov.on.ca/Page6054.aspx

Murray, L. (2015, January 9). Let's do what Macdonald didn't. Ottawa Citizen. Retrieved from http://ottawacitizen.com

Murray, L. (2015, January 9). Sir John A. Macdonald: Nation builder or racist? Toronto Star. Retrieved from https://www.thestar.com

Office of the Correctional Investigator. (2013). Backgrounder: Aboriginal Offenders - A Critical Situation. Retrieved from the Government of Canada website: http://www.ocibec.gc.ca/cnt/rpt/oth-aut/oth-aut20121022info-eng.aspx

Ogimaa Mikana Project (2013-). Ogimaa Mikana: reclaiming/renaming. Retrieved from http://ogimaamikana.tumblr.com/

Ontario Heritage Act (1990, c. O.18). Retrieved from the Ontario Provincial Government website: https://www.ontario.ca/laws/statute/90o18

Pollack, S. (2008). Locked in, Locked out: Imprisoning Women in the Shrinking and Punitive Welfare State. Elizabeth Fry Society Ottawa. Retrieved from http://www.efryottawa.com/documents/LockedinLockedoutSPollockresearchreport.pdf

Procedural By-law for Heritage, By-law 2013-141 of the City of Kingston. (2013). Retrieved from the City of Kingston website: https://www.cityofkingston.ca/documents/10180/3109532/ Procedural+Bylaw/b60e1832-da8d-40ee-a9ec-17944656654b

Public Safety Canada. (2012). Marginalized: The Aboriginal women's experience in federal corrections. Retrieved from Public Safety Canada website: http://www.publicsafety.gc.ca/cnt/rsrcs/pblctns/mrgnlzd/index-en.aspx

R. v. Gladue, Supreme Court Judgments Report 1 SCR 688. (1999, April 23). Retrieved from the Department of Justice Canada website: https://scc-csc.lexum.com/scc-csc/scccsc/en/item/1695/index.do 
R. v. Ipeelee, Supreme Court Judgments Report 1 SCR 433. (2012, March 23). Retrieved from the Department of Justice Canada website: https://scc-csc.lexum.com/scc-csc/scccsc/en/item /8000/index.do

Rankin, J., \& Winsa, P. (2013, March 1). Unequal justice: Aboriginal and Black inmates disproportionately fill Ontario jails. Toronto Star. Retrieved from https://www.thestar.com

Shannen's Dream: Timeline and Documents. (2010-). First Nations Child \& Family Caring Society of Canada. Retrieved from https://fncaringsociety.com/shannens-dreamtimeline-and-documents

Sherwin, A. (2012). Bridging Two Peoples: Chief Peter E. Jones, 1843-1909. Waterloo, ON: Wilfrid Laurier University Press.

Sinclair, N. (2015, January 9). Stop apologizing for John A. Macdonald. Ottawa Citizen. Retrieved from http://ottawacitizen.com

Sir John A. Macdonald Bicentennial Commission. (2012). Funding Request to Kingston City Council. In Beach, C. Report to Council 13-048, December 18, 2012. Retrieved from the City of Kingston website: https://www.cityofkingston.ca/documents/10180/43928/COU_A021313048.pdf/ca873eb6-04df-40b0-9ee4-afb7767cb122

Sir John A. Macdonald Bicentennial Commission. (2013). Funding Request to Kingston City Council: Introduction. In Beach, C., Report to Council 12-374, November 19, 2013, 75-110. Retrieved from the City of Kingston website: https://www.cityofkingston.ca/documents/10180/3050121/COU_A241313374.pdf/debcf5b4-c637-4398-a607-a3c268a87620

Solicitor General of Canada. (1996). Commission of Inquiry into certain events at the Prison for Women in Kingston. Retrieved from http://justicebehindthewalls.net/resources/arbour_report/arbour_rpt.htm

St. Joseph's Catholic School. (2014, November 14). In Facebook [Group page]. Retrieved from

https://www.facebook.com/permalink.php?story_fbid $=542608089217442 \& i d=136277$ 103183878

Thurston, Lance (2006, October 3). Report to Council 06-232: Belle Island Cultural Heritage Site Protection Strategy. Retrieved from the City of Kingston website: https://www.cityofkingston.ca/cok/council/agenda/2006/A21_Rpt110.pdf

Totem pole reflects desire for brotherhood. (1973, July 30). Kingston Whig-Standard. 
Truth and Reconciliation Commission of Canada. (2015). Honouring the truth, reconciling for the future: summary of the Final Report of the Truth and Reconciliation Commission of Canada. Retrieved from the Truth and Reconciliation Commission of Canada website:

http://www.trc.ca/websites/trcinstitution/File/2015/Honouring the_Truth_Reconciling for the Future July_23_2015.pdf

Vandenbrink, D. (2013, January 11). Sir John A. statue vandalized. Kingston Whig-Standard. Retrieved from http://www.thewhig.com

Winks, R. (2014). The Blacks in Canada: A History (2 ${ }^{\text {nd }}$ ed.). Montreal, QC \& Kingston, ON: McGill-Queen's University Press. 